\title{
Youth Activism in Chile: from urban educational inequalities to experiences of living together and solidarity
}

Ivette Hernandez Santibañez'

'University College London (UCL), London - United Kingdom

\begin{abstract}
Youth Activism in Chile: from urban educational inequalities to experiences of living together and solidarity ${ }^{1}$. This article examines the geographies of youth political activism in Chile. It makes the argument that a historical spatial identity of public education, as the engine of workingclass and middle-class mobility, intersecting both with contexts of social mixing and with a historical urban educational inequality, provides a different lens through which to understand youth activism. This article seeks to analyse the linkages between these spatialities of public education and different geographies of youth activism as spaces of living together and as practices of solidarity. It reflects on the need for ongoing debates on citizenship education to engage with these geographies of youth activism in order to fully understand the significance of youth political participation within neoliberal market-driven education agendas.

Keywords: Chilean Student Movement. Youth Activism. Public Education. Citizenship.
\end{abstract}

RESUMO - Ativismo da Juventude no Chile: das desigualdades educacionais urbanas às experiências de convivência e de solidariedade. Este artigo examina as geografias do ativismo político da juventude no Chile. Defende que uma identidade espacial histórica da educação pública, sendo motor da mobilidade da classe trabalhadora e da classe média e fazendo a interseção tanto com contextos de combinação social como com uma desigualdade educacional urbana histórica, fornece uma lente diferente para compreender o ativismo da juventude. Este artigo procura analisar os vínculos entre estas espacialidades da educação pública e as diferentes geografias do ativismo da juventude como espaços de convivência e como práticas de solidariedade. Reflete sobre a necessidade de que os debates continuados a respeito da educação para a cidadania envolvam estas geografias do ativismo da juventude, com a finalidade de compreender plenamente a importância da participação política da juventude nas agendas neoliberais da educação voltada para o mercado.

Palavras-chave: Movimento Estudantil Chileno. Ativismo da Juventude. Educação Pública. Cidadania.

Educação \& Realidade, Porto Alegre, v. 43, n. 3, p. 837-862, July/Sept. 2018. 
Youth Activism in Chile

\section{Introduction}

For the last ten years Chilean students have been mobilised and have taken part in escalating political protests demanding a radical overhaul of the Chilean education system. Between April and June 2006, hundreds of thousands of high school students, known as the Penguins because of their black and white school uniform, mobilised across the country to demand that education should be a right, not a privilege. Five years later, in 2011, university students, many of whom had been school pupil activists involved in the Penguins' movement in 2006, mobilised in the largest Chilean student protests in the post-democratic transition era to demand a radical reform of the market-oriented education system. The Chilean student movement has successfully transformed the public policy agenda on education (Bellei; Cabalin, 2013), but this student movement has also challenged the nature of the democratic transition process in the Chilean context by legitimising political protest and public mobilisation as quintessential elements for democracy building and new forms of democratic engagement and citizenship.

In the context of the Latin American region, youth political participation has become "[...] an emergent topic in the political agenda of several governments [in] the region" (Treviño et al., 2017, p. 604). This, in turn, has opened up questions regarding the role of youth participation in transforming and deepening the very nature of democracy within democratic transition societies, which still show democratic deficits at an institutional level and in the "[...] constructive function in the formation of values" (Sen, 1999a, p. 16) or in creating more spaces of co-governance (Gaventa, 2006). Analysis of new forms of youth political engagement provides evidence of the production of horizontal and non-hierarchical radical democratic politics (Hernandez, 2017) in the margins of traditional political parties, yet alongside this, low turnouts at elections (Alvarado; Vommaro, 2012; United Nations Development Programme, 2009; Latin American Public Opinion Project, 2012). The evidence also suggests that Latin American youth tends to underperform internationally (Schulz et al., 2010) in relation to civic knowledge. Studies also show that young people recognise themselves as fundamentally mistrustful towards democracy and democratic institutions (Cox; Jaramillo; Reimers, 2005; Reimers, 2007; Economic Commission for Latin American and the Caribbean, 2008; United Nations Development Programme, 2009).

Research on the relationship between education and the formation of civic knowledge and democratic attitudes is also well documented. The research shows different tendencies in the role that education plays out. On the one hand, evidence shows a strong correlation between education and the formation of civic attitudes (Campbell; Levinson; Hess, 2012; Isac et al., 2014; Torney-Purta, 2002; Castillo et al., 2014a). While on the other hand, studies also reveal that socio-economic status deepens inequalities in levels of civic knowledge, with upper-middle class students performing better than low-income students (Delli Carpini; Keeter, 1996; Hooghe; Dasonville, 2013; Scholzman et al., 2012; Schulz et al., 2010; Castillo et al., 2014b; Schulz et al., 2011).

838 Educação \& Realidade, Porto Alegre, v. 43, n. 3, p. 837-862, July/Sept. 2018. 
This article agrees with the role education plays out in influencing the formation of democratic values and in enabling conditions for different forms of youth political activism and participation to be produced. Nevertheless, it problematises how this political role of education is normally "[...] materialised through dominant forms and practices of citizenship" (Turner, 2016, p. 141), broadly framed within a binary distinction of inclusion/exclusion. Scholarship on citizenship and inclusiveness often explores this tension through the lens of human rights (McCowan, 2010; 2012; Starkey, 2012a; 2012b; Kiwan, 2012). Scholars working on exclusion (Muller, 2004; Nyers, 2009; Guillaume; Huysmans, 2013; Mezzadra; Neilson, 2013; Papadopoulus; Niamh; Vassilis, 2008; Rigo, 2005; Roseneil et al., 2013) examine the meaning of citizenship as "[...] an inherently exclusive mode of political subjectivity" (Turner, 2016, p. 142). This focus on inclusion/exclusion has produced valuable scholarly contributions to a better understanding of the complexities of assemblages of exclusion and inclusion through which citizenship is made. Yet Turner (2016, p. 142) argues that there is an absence in the literature of exclusion regarding the "[...] analysis of the emergence of political events [and] moments of resistance". In his argument, Turner notes that this process, which is profoundly spatial because of the heterogeneity and diversity of the political that it reveals, is commonly obscured. This article is concerned with exploring these diverse forms of youth political engagement and activism through "[...] thinking in terms of relations" (Massey, 1999, p. 12) between spatialities of inclusion and exclusion in which education is embedded. It suggests that current research on the relationship between education and citizenship frames such relationships within a negative relation of inclusion/ exclusion based on students' socio-economic backgrounds.

This article seeks to "[...] recognise the important elements of interconnection which go into the construction of any identity" (Massey, 1999 , p. 12) by looking at public education as a spatial identity 'sedimented over time' (Massey, 1984), forged in socio-economic terms but not just limited to them. The article first draws upon recent exploratory study of space and politics in the Chilean student movement. It explores through this empirical research the relationship between education and youth political activism. Within a context in which political and economic neoliberal practices sought to transform public education identity under "[...] the logics of commodification, marketization, competition, and cost-benefit analysis" (Apple, 2013, p. 6), there is a need to think spatially about the relationship between education, schooling experience and youth activism. This entails recognising "[...] the production of geographical imaginaries" (Hanson Thiem, 2009, p. 161) that connects with both formation of neoliberal governmentalities of global citizen-subjects (Larner, 2000; Mitchell; Marston; Katz, 2004; Thrift, 2005; Laurie; Bondi, 2006) and alternative forms of becoming political. This article adopts such a spatial analysis by highlighting that forms of youth political activism - being made through interconnected spatialities of exclusion and inclusion - constitute explanatory moments (Hanson Thiem, 2009) through which to critically interrogate a curriculum for civic and citizenship education. The second part goes on to contexEducação \& Realidade, Porto Alegre, v. 43, n. 3, p. 837-862, July/Sept. 2018. 
Youth Activism in Chile

tualise youth political activism within a spatial identity of public education. It reflects on how a dynamic process of engineering class mobility has forged a spatial identity of education, which in turn has fostered a historical tradition of youth activism at the group of the oldest public schools, known as the emblematic schools, in Greater Santiago ${ }^{2}$. The third section reflects on daily schooling experience and performativity of the self within spatial differentiation between centre and periphery. This article argues that such residential geographical differentiation does not entail recognising preconstituted identities based on where students come from. Rather, the imagination of the self and the constitution of the political are always in flow. The fourth and fifth sections analyse spaces of living together and practices of solidarities as experiences of the political, which in turn shape different geographies of youth political activism. Finally, this article discusses wider implications for civic and citizenship education that could further connect with alternative forms of the political and youth activism.

\section{The Study, Research Context and Methods}

This article draws upon a larger cross-disciplinary qualitative study on space and politics in the Chilean student movement. The Chilean education system was radically transformed during the 1970s by an economic policy ideologically adhering to the "Chicago school of neo-liberalism" (Van der Ree, 2007, p. 195), and during the 1980s with the introduction of school choice reform that reflected a much stricter adherence to free market regulation in education. Between 1990 and 2010 four democratically elected governments from a coalition of centre-left parties known as the Concertación ${ }^{3}$ assumed office and led the implementation of a mixed educational agenda of equity and quality first implemented in the early 1990s. This was based on the idea of "[...] market or choice models and state or integration models" (Cox, 2003, p. 19) as "[...] the optimal route to make quality education available for all" (Hernandez, 2013, p. 188).

Between March and June 2006, high school students protested and mobilised across the country to demand free quality education for all by questioning and pointing out the failure of educational policies related to equity and quality. Through cross-disciplinary qualitative research involving sociology of education, critical geography and sociology of social movements this study aimed at understanding the emergence of the Penguins' movement by examining this movement as a constructive process of collective identity. It explored the origins of the movement and analysed how space and politics form the basis for its collective identity. It further investigated elements of continuity and discontinuity that enabled aspects of this student movement to undergo transformation between 2006 and 2011.

This research was undertaken between early July and November 2011 in Greater Santiago. Empirical data was collected through in-depth interviews with student activists, teachers, policy-makers and academ-

840 Educação \& Realidade, Porto Alegre, v. 43, n. 3, p. 837-862, July/Sept. 2018. 
ics, and through secondary sources including official documents, academic editorials, and newspapers. Nevertheless, this paper draws only on data collected through in-depth interviews with student activists. A snowball process was chosen as the method for finding and contacting high school students from 2006. Gathering data was affected by the massive 2011 student mobilisations that took place while this research was conducted. Because many pupils from 2006 were involved, as university students, in the 2011 student mobilisations, research participants were approached during local assemblies they carried out in their faculties, contacting them during the marches that students called in Santiago city centre, and attending either the Assemblies they called for at the Main House of the University of Chile or debates and seminars they coorganised at campus occupations in the communes of Santiago, Macul, and San Joaquín in Greater Santiago.

The decision to collect data in this way is consistent with the idea that "[...] the researcher must make a leap of faith and just dive into the process" (Johnson, 2001, p. 108) to understand "[...] what is happening here" (Glaser, 1978), that is, "[...] the basic social process that the research discovers in the field" (Charmaz, 2014, p. 34). Twenty-four research participants who had been high school students engaged in the mobilisation of 2006 were interviewed; twenty-two interviews were carried out in the commune of Santiago and the other three in the communes of Macul and Nuñoa in Greater Santiago (See Image 1).

\section{Image 1 - Map 1: location of interviews conducted between July and November 2011}

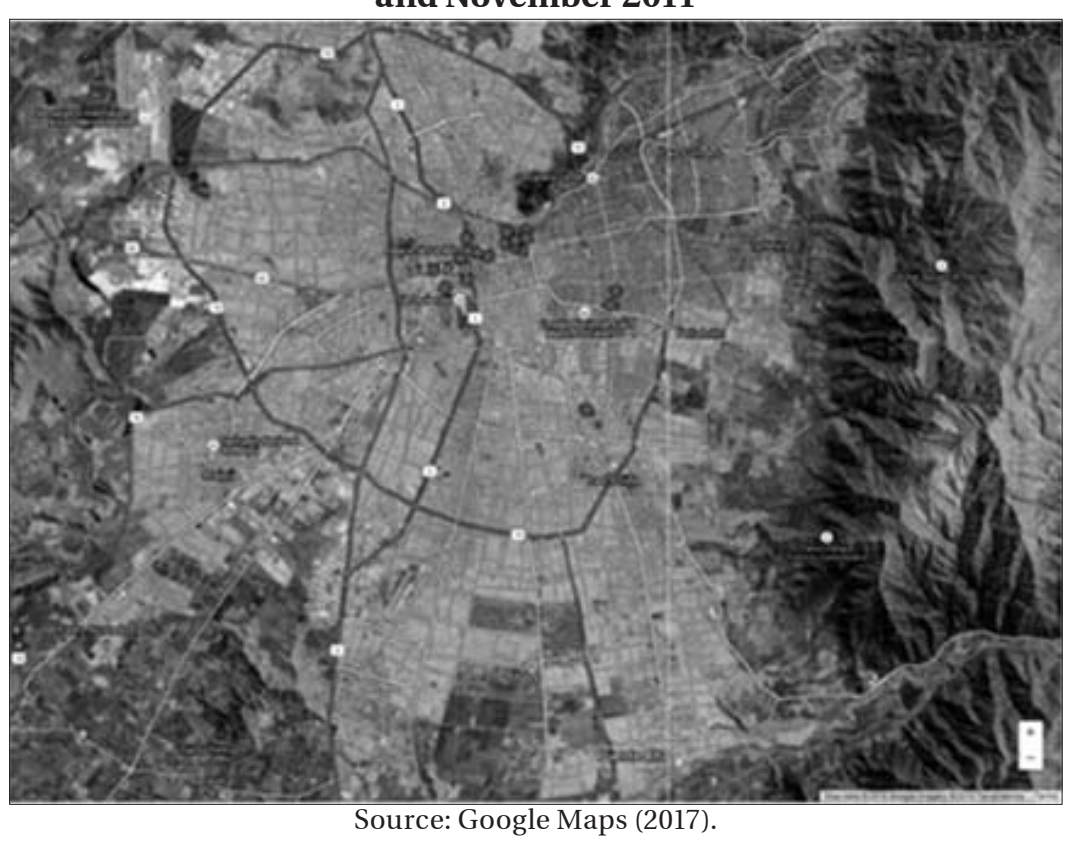

Educação \& Realidade, Porto Alegre, v. 43, n. 3, p. 837-862, July/Sept. 2018. 


\section{Youth Political Activism in Context: spatial identity of public education}

In Latin American societies, in the early twentieth century the middle class and organised blue-collar workers became significant political actors, and to some extent were able to lead processes of social transformation that had historically relied upon a "[...] private domain of traditional elites" (Roberts, 2002, p. 10). In the context of Chilean society, the rise of the middle class and the "[...] sustained growth of the urban working class" (Taylor, 2006, p. 13) led to reforms and transformations of the public education system before 11 September 1973, positioning public education as "[...] a larger emancipatory impulse" (Apple, 2013, p. 151). This trajectory of middle-class and working-class formation has, however, been drastically transformed during the last four decades. Such structural class transformation, particularly because of the effects of neoliberal economy policies during the Pinochet regime and the governments of the Concertación, led to the emergence of a new middle-class group through massive expansion of private-voucher schools and the private higher education sector (Ruiz Encina; Boccardo, 2015; Bellei; Cabalin, 2013).

Historically, public schools across the country were established at the beginning of the last century as necessary for a "[...] national democratic development project for modernisation” (Nuñez, 1979, p. 13). Education and "[...] its connections to processes of social transformation" (Apple, 2013, p. 151) led to the formation of a historical identity of public education as the engine of middle-class and working-class mobility. This identity has been traditionally produced in the oldest public high schools across the country. The most representative of these are the group in the communes of Santiago and Providencia, historically known as the Alameda Cordon and later as the emblematic schools (See Image 2). 
Image 2 - Map 2: the emblematic schools in Greater Santiago

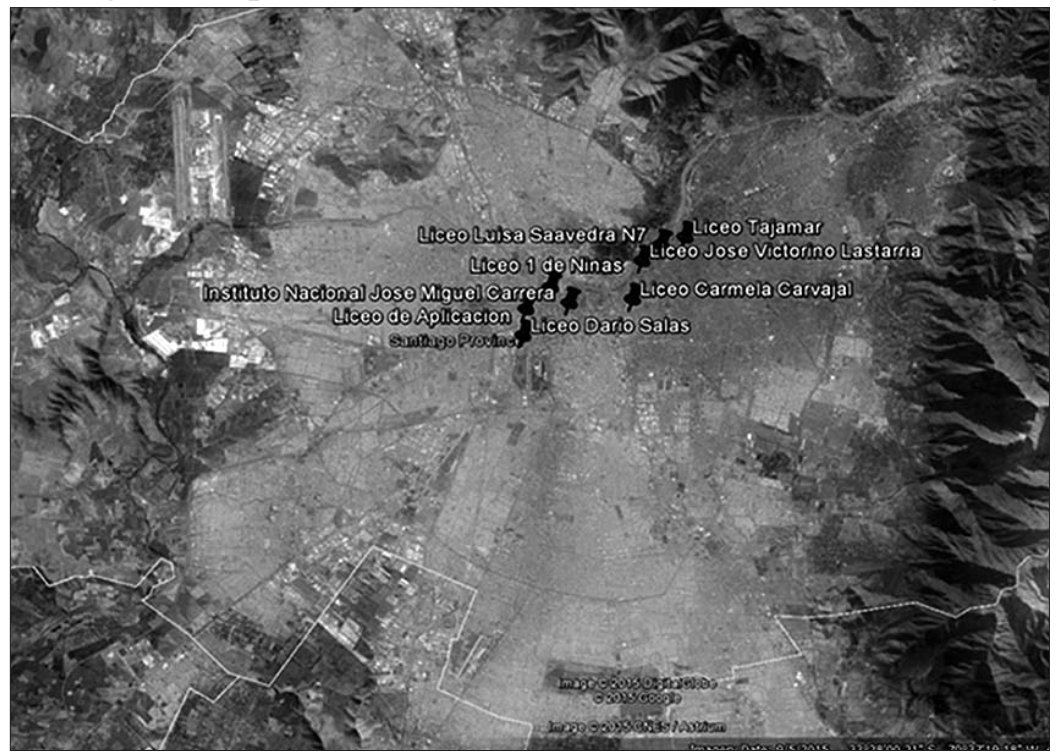

Source: Google Maps (2017).

It is this identity, as the generative past (Lefebvre, 1991) of public education, that has historically underpinned the formation of the middle class and its political role in leading social movements deeply connected to the idea that education itself has an intrinsic value (Sen, 1999b). This evokes the reasons why this middle-class group has always been historically mobilised:

Well the old middle-class sectors have always been mobilised; we could say the most traditional middle-class group. And they historically mobilised because they defended the idea that education is not an exchange value, that is, they defended education as a use value...I mean education worth the education (Interview with Sebastián, 2011).

Their historical formation through public education and their leading role in larger social transformations of society have shaped a long-standing tradition of student political activism at the group of emblematic schools where they have traditionally been educated:

Well, all of them are old public high schools with fifty years of existence at least; I could tell you that the old Chilean enlightened middle class was educated here...I mean the Nacional ${ }^{4}$, the Liceo de Aplicación, the public girls' high schools such as the Carmela Carvajal... I believe that the presidents that Chile has had so far were educated at these schools [...]. There is a lot of political tradition at these schools too. Since these schools have a larger number of students, then one is likely to find militants in a class of 45 students, get it? Yet it was different in a municipal high school or a subsidised school in the periphery; I mean in a class of 30 or 28 students nobody talked about politics. Here it was another context and I think it happened in all of these older schools (Interview with Alejandra, 2011). 
Youth Activism in Chile

Alejandra expresses a widespread idea that students at these politicised schools commonly came either from families with a history of political involvement through militancy or grassroots activism or from middle-class families that "[...] simply reflect the traditional inclination of the intellectual middle class to [...] participate in political life" (Porta; Diani, 2006, p. 56; Bagguley, 1995; Pakulski, 1995, Bourdieu, 1984). This, however, does not entail confining this historical tradition of youth political activism to just traditional politics. Rather, forms of student activism and youth political engagement are largely explained by the existence of colectivos within the secondary student movement. Although there is no rigorous study of when colectivos emerged, they seem to date back to the early 1990s and to be recognised as groups comprising a multiplicity of different subcultures. They are recognised as "[...] smaller group[s] of students that represented the inorganic Left" (Donoso, 2013, p. 6), and which exist in the margins of traditional politics.

The historical formation of the middle class remains a longstanding salient political identifier of student activism at the emblematic schools. Yet it would be misleading to characterise this just as a specifically middle-class action. Rather, the relationship between class mobility and forms of student activism is depicted as a dynamic process interconnected with experiences of poverty, parents' educational background, political biographies, and educational aspirations that finally end up forging different geographies of social mobility and provide conditions for different forms of youth political activism.

Image 3 - Map 3: high school students commuting in the metropolitan area of Greater Santiago (2006)

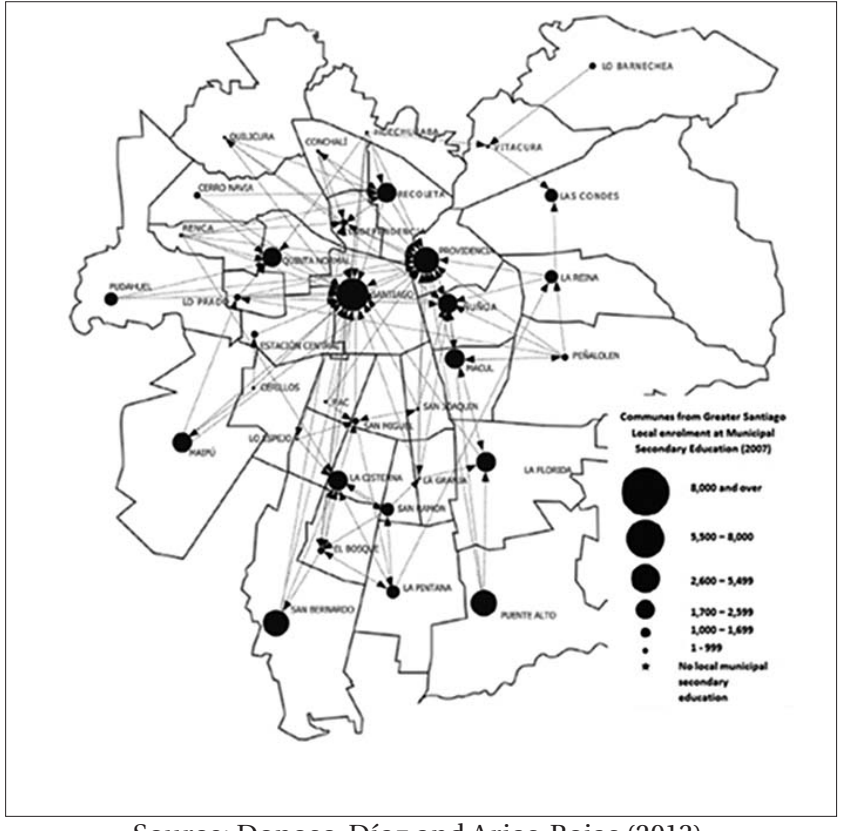

Source: Donoso-Díaz and Arias-Rojas (2013). 
About $50 \%$ of students within urban communes of Greater Santiago commute daily to schools (Donoso-Díaz; Arias-Rojas, 2013) (See Image 3). This student commuting pattern can be better understood in relation to a spatial urban inequality in which the communes of Santiago and Providencia have historically driven the centrality of socio-economic, political and cultural urban development in Greater Santiago. It is this unequal socio-economic urban development that has historically triggered the emblematic schools in an inter-city competition (Lipman, 2004). Therefore, disadvantaged neighbourhoods and low socioeconomic backgrounds play out in the class-mobility aspirations of working-class students who commute daily to the emblematic schools:

There were many students who were like the typical smartest student in their class in the peripheral commune. They took an exam to enter a school in Santiago and Providencia from which they promise you can go on to a university [...]. Thus, they are people who have [...] they came from middle and lower-middle socio-economic groups. Then they access a socio-cultural level, which does not correspond with their own socioeconomic background (Interview with Alejandra, 2011).

Within a context in which meritocracy seems to come "[...] to dominate the discourse and policies in education" (Apple, 2013, p. 7) academic selection at the emblematic schools, along with the competition to get into these schools, became partly counter-hegemonic to education "[...] saturated with neoliberal common sense" (Fraser, 2015, p. 86). This is partly because academic selection at these schools has been historically constituted through the identity of public education as the engine for middle-class and working-class mobility. Meritocracy at these schools is acknowledged as socio-cultural disposition enmeshed in the idea of education and social justice through equal opportunities for free public quality education.

In relation to this last point, it is important to highlight that such a spatial identity of public education could be seen as "[...] the layers of history which are sedimented over time” (Massey, 1984, p. 120), not just in economic terms but as "[...] cultural, political and ideological strata, layers which also have their local specificities” (Massey, 1984, p. 120). This identity of public education becomes spatial as it is forged in and through social mixing at the emblematic schools. Nevertheless, it has been historically contested as academic selection has undermined the democratic development of the Chilean education system. This is because democratisation of education, credited with engineering social mobility, did not coalesce around a common idea of whether such democratisation might or might not mean the elimination of academic selection at the emblematic schools.

At the same time, neoliberalism attempts to open some identities “[...] and closes down others" (Apple, 2013, p. 7) by framing narratives of meritocracy as an individual enterprise and driven by the idea of quality education as “[...] one's choice of products" (Apple, 2013, p. 7). Yet different geographies of social mobility, historically sedimented over time, encompass the possibility of contesting neoliberalism as these 
geographies of social mobility do not just refer to those who come to these schools but to why they value education.

Whilst interconnections between this spatial identity and student commuting patterns at the emblematic schools typify contrasts between "[...] marginality and centrality" (Lipman, 2011), it also opens up questions regarding the effects of residential areas and the "[...] neighbourhood contextual effects" (Garner; Raudenbush, 1991) on the tradition of youth political activism when students from peripheral areas commute to schools in Santiago and Providencia. In the following section, attention is drawn to the everyday schooling experience and the extent to which it offers, through the relationship between marginality and belonging, the possibility for students to become political subjects.

\section{Everyday Schooling Experience and the Re-Imagination of the Self}

Education, as Lipman (2007, p. 157) argues, is “[...] central to struggles over capital accumulation, cultural appropriation, and domination in the city" where its relationship to urban inequality commonly frames public education identity at schools from peripheral areas within a presumed homogeneity (Posey-Maddox, 2014) about what students could do (or could not do) because of the disadvantaged economic backgrounds from which they come. This is implicated in poverty and larger gaps in terms of income levels (See Image 4) that have profoundly shaped both inner geographies of class mobility and educational aspirations socially constrained by urban segregation in some peripheral communes from Greater Santiago. What are the implications when children from lowincome peripheral areas commute? It could be argued that commuting plays a role in forging construction of subjectivities and re-imagination of the self. Yet this production might display different interpretations when students commute to communes with higher, lower, or similar inner urban segregation. This is because living in and commuting from the periphery is not simply a temporal experience but rather is forged in and through trajectories and networks (Allen; Massey; Cochrane, 2000), which although they are locally influenced, are always in flow. 


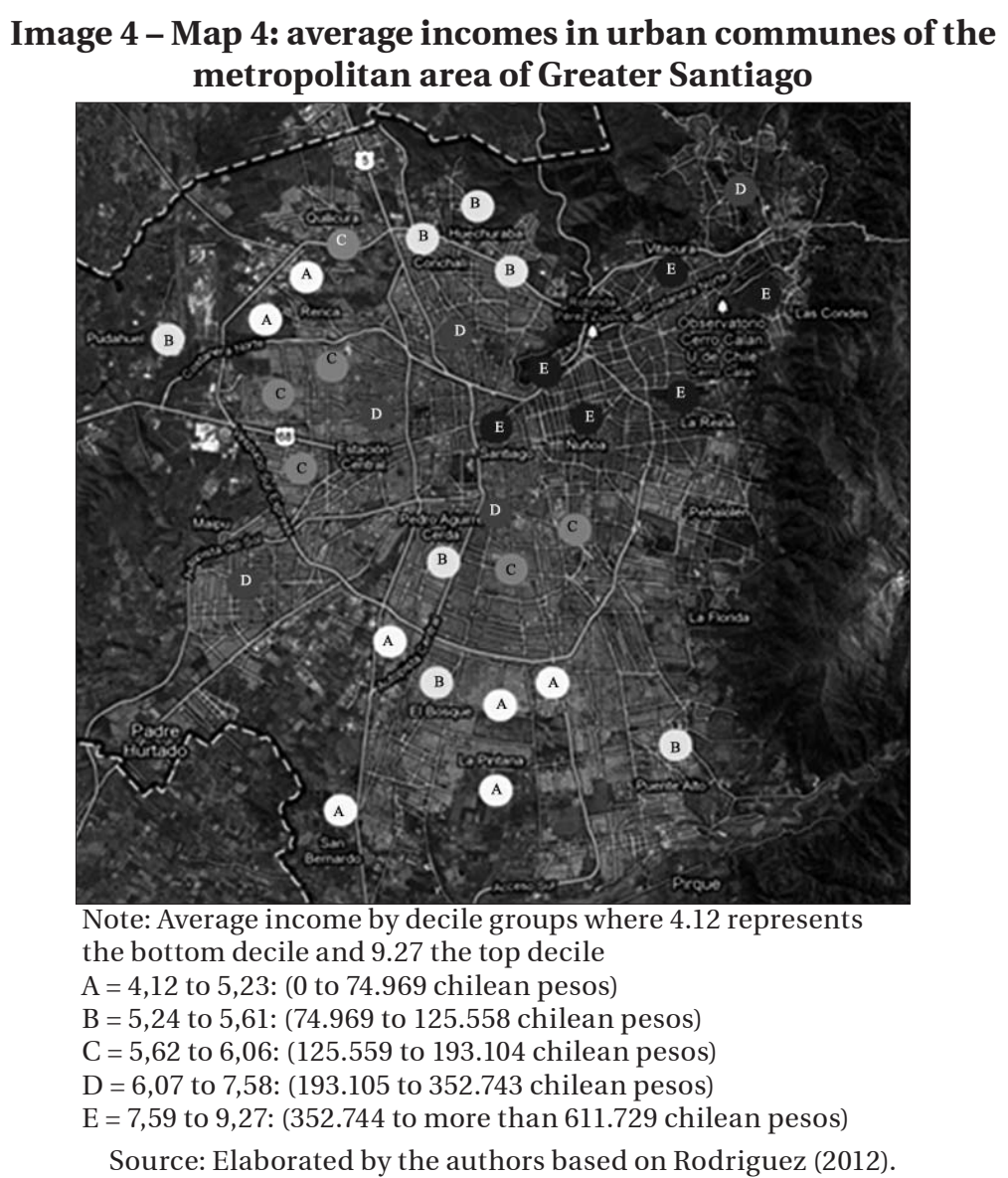

Different schooling experiences seem to be shaped by the idea of the centrality of socio-economic development, mainly in the urban centres of Santiago, Providencia and Nuñoa (See Image 3) where economic, social, political and cultural contexts reframed the schooling experience itself. For students commuting daily to central communes, schooling experience becomes a very different “[...] material manifestation of social practice" (Thomson, 2007, p. 113) of what is "[...] readily visible and apparent" (Thomson, 2007, p. 113), something very different from what was knowable and lived by them in their original communes:

It was a big change when I studied at the Liceo 1 . This was because it is a high school in Santiago city centre. I commuted alone, and many doors are opening as one is where things happen; I had a lot of contact with another reality, with other different things, shops, and other schools. The school has more than 3,000 students, thus I got to know other realities (Interview with Kari, 2011)

How identities and re-interpretation of the self are re-made is a process in flux, traversed and transformed by encountering points of diversity and heterogeneity at these schools. Spatiality of the schooling 
Youth Activism in Chile

experience seems to be depicted as an enabling process because of the very different socio-economic, political and cultural capital with which it is imbued and the effects this has on how students who commute from peripheral communes to Santiago city centre (re)interpret themselves:

Well I came to the Instituto Nacional and it was a different world. It was different travelling every day and for one hour on the bus to Santiago city centre. All my classmates were well educated [...]. At the Instituto I faced a different world as I had some classmates from a very good economic situation and others who were very poor... or classmates who were leftwing militants and other ones with right-wing ideas. It was a very active world $[. .$.$] and one very different from to the world I come from in the$ shantytown. Yet I did not lose my sense of identity; I mean to know where I came from. At that moment I began to embrace the tradition of being a leftist militant, in particular, when I saw some classmates who became bourgeoisified, in inverted commas, in these spaces. This made me very upset (Interview with Andre, 2011).

If identity is relationally constructed, then the decision to become a leftist militant is spatial as it follows a path that is "[...] not immutable or naturally given” (Soja, 2004, p. 10) but rather embedded in learning how to live with others and co-exist with a multiplicity of biographies and trajectories. In addition, affirmation of where one comes from is seen as a space of resistance through which students, who recognise themselves as being excluded, might affirm themselves in a more positive sense:

The Carmela is the best girls' school. It is not because it has the best teachers but because it selects its students; it is very clear that the Carmela has a good level of education because it selects the poorest girls, the smartest poorest girls from Santiago (Interview with Pat, 2011).

Self-affirmation as the smartest poorest students becomes a space of resistance, as the way in which students from peripheral areas “[...] can collectively appropriate space" (Thomson, 2007, p. 123) to resist and oppose, through the politics of self-affirmation, a presumed narrative of working-class mobility about what students could do (or could not do) because of the disadvantaged economic backgrounds from which they come. The politics of self-affirmation navigates this schooling experience in between "[...] geographies of inequality, centrality and marginalisation" (Lipman, 2007, p. 158). This suggests the possibility of thinking of such a politics as beyond the inclusion/exclusion dichotomy but rather as an everyday temporal-spatial experience of resistance always in flow.

Schooling experience and re-affirmation of the self are experiences represented in different ways. Since they involve reimagining identities and practices differently and positioning the self creatively, the politics of self-affirmation is more conducive to re-envisioning new forms of activism and political agency when young people navigate through everyday lived schooling experience emerging through spatialisation of urban educational inequalities. This trajectory of working-class students could lead to a richer understanding not only of the relationship 
between schooling experience, marginality and belonging, but also of how these identities are constituted themselves in contexts of social mixing at the emblematic schools. It is to different spatialities of student activism that this article turns now, seeking to explain how this context of social mixing provides the basis for the possibility of producing spatial identities of youth political activism at these schools.

\section{What Diversities, What Spatiality of Student Activism at Emblematic Schools?}

A spatial political identity of youth activism at the emblematic schools is detached from the idea that it is accounted for solely by their previous history as a place identity imbued with "[...] an atmosphere of earthiness, authenticity, meaning” (Massey, 2004, p. 5). Indeed, the multiplicity of biographies and trajectories encompassing a spatial identity of public education at the emblematic schools means that we cannot rely for an understanding of different geographies of student activism simply on pre-given identities of either leftist students or students coming from leftist families. It does not deny that the emblematic schools have, like “[...] every social space [,] [...] a history” (Lefebvre, 1991, p. 110). For example, political identity - to be precise left-wing political identity at the emblematic schools is acknowledged as an identity endowed with a long-standing history of student political activism against Pinochet's dictatorship:

A quite well-known leftist culture exists at the Dario Salas with teachers and students who became missing or detained persons during the dictatorship; the same happens at the Nacional [...] and at the Aplicación $n^{5}$ too... get it? It is like a context (Interview with Alejandra, 2011).

While the long history of social mobility and student political activism at these schools equates to the idea of a generative past (Lefebvre, 1991) of politics, this process per se is neither monolithic nor static. These historical trajectories of student political activism are, undeniably, constitutive elements of the diversity of political capital existing at these schools. However, they do not reveal themselves as a unique pattern underpinning the production of youth political activism at these schools. Rather, the production of particular political class identities and their long-standing historical tradition are determined by different assemblages such as socioeconomic and cultural conditions which, in turn, provide a more complex understanding of the production and meaning of youth activism:

The Darío Salas has always been a high school for working-class sectors. High levels of student protests have taken place at the school as the Liceo has always represented the encountering point of different social groups. Furthermore, this has also been fed by working-class sectors with a long tradition of political struggles, like Pudahuel ${ }^{6}$. Nobody from the new communes that the dictatorship created after slum eradications comes here where neither roots nor identity nor a tradition of political struggles 
Youth Activism in Chile

exists. Here, lads come from Estación Central, the Villa Francia ${ }^{7}$ to study at the Dario Salas (Interview with Gaspar, 2011).

Processes of marginalisation and gentrification show the relationship between youth political activism and “[...] the persistent struggle over belonging" (Turner, 2016, p. 141). This meaning of belonging connects with the history of working-class political struggles out there and to some extent it is enmeshed in claims of authenticity on the left. A further element of this is the idea of representation of these leftist identities as already "[...] inscribed in a pre-existing space" (Lefebvre, 1991, p. 78) through which youth political activists recognise themselves as the inheritors of past tradition. Discussion of the extent to which previous experiences of working-class struggles might or might not interfere with the production of different spatial identities of youth activism does not entail recognising beforehand what spatial identities of youth activism exist. This, however, does not mean denying the historical and political role of the working class. Yet what is being discussed here is the idea of a bounded leftist political identity of student activism to be constructed through exclusion of others who neither share similar historical trajectories nor live in the same geographical area.

The discussion therefore is focused on acknowledging that such spatialities of youth activism could be produced through "[...] the specificity of their interaction" (Massey, 1994, p. 121) with other trajectories out there or "[...] by counterposition to them" (Massey, 1994, p. 121). This last point entails recognising that the long-standing tradition of student activism at the emblematic schools resembles an ethos sustained and developed across time because of "[...] difference [and] a non-essentialist politics of interrelationships” (Massey, 1999, p. 285):

What was known as the Alameda Cordon includes all mobilised schools, the most politicised schools that have small political colectivos, which include anarchists, ex-communist militants; I mean a lot of cultures of the diverse left wing from this country [...]. In parallel, a political culture comprises the traditional militants whose parents were either communists or militants in the Concertación. Perhaps this guy, because of either his family's political history or his own initiative, followed a political career as a small politician while he was a high school student. In fact, I remembered some of them and I have heard about them in the media as they ended up involved in traditional politics and working for the government (Interview with Alejandra, 2011).

The way in which youth political activism at these schools is (re) produced characterised spatial identities of activism as the co-existence of different trajectories. Some forms of youth activism would be enmeshed in a meaning of politics as an absolute idea in which activism seems to (re)produce and maintain continuity of spatial practice of politics within particular physical places, as offices and ministries where traditional politics ended up being (re)produced. At the same time, this meaning of an absolute idea of politics co-exists with recognition of the diversity that the left encompasses. As such, the production of politics reproduces, because of diversity, a similar condition to that identified 
by Harvey (2006, p. 125) in which “[...] space is neither absolute, relative or relational itself, but it can become one or all simultaneously depending on the circumstances".

Possibilities for building different spatial identities of youth political activism and for how they are conceptualised will depend on who inhabits those spaces and how it is "[...] that different human practices create and make use of different conceptualisations of [those] spaces" (Harvey, 2006, p. 126). Diversity of socioeconomic, cultural, and political backgrounds forges the condition of social mixing which underpins the (re)production of different spatialities of youth activism. Nevertheless, it could be suggested that diversity does not just refer to "things in space" (Lefebvre, 1991, p. 37). Rather it is about how diversity engages in the production of spatiality of politics and activism as learning to live together. This argument links to the idea that the production of spatial identities of youth political activism is "[...] relational [...] constituted in and through those engagements, those practices of interaction" (Massey, 2004, p. 1). This does not deny that we, as social human beings, come with personal trajectories "[...] imbued with power and meaning and symbolism” (Massey, 1994, p. 3) that determine to some extent what our initial position on the map of social power relationships would be. Yet what it is important to emphasise here is that diversity and the possibilities for encountering others different to us make the conditions for reframing our initial position through a process in which one re-imagines oneself and one's social relations differently but in relation to others:

There are many people... one has to learn how to live with others who came from different communes and with very different socioeconomic backgrounds too [...]. I had classmates whose parents were professionals and I had classmates whose parents sold sweets on the buses, get it? Then all this diversity gives you another social contact [...] it causes you to adapt to it, to develop forms to relate to [...] I think it opens your mind and consciousness in a radical way, very profound [...] and it obviously gives you many more expectations and horizons in your life (Interview with Alejandra, 2011).

Heterogeneity and equality of educational opportunities regardless of the different socioeconomic backgrounds students come from underpin the engine of different geographies of youth political activism. Appreciation of difference and tolerance is what has commonly been ascribed to the construction of identities and the specificity of these interactions when exploring youth politics and activism at these schools. Nevertheless, it is, as Massey (2005) argues, the practices and relations and what is contained in this process that need to be taken into account. A further element is that both appreciation of difference and tolerance are themselves a political decision to be taken by everyone who exists in space as it entails posing the collective political question of how we, although, different from each other, could learn to live together. Central to this is the idea that this political decision is grounded in students' own everyday practice. Neither the recognition of others 
Youth Activism in Chile

as equals nor the attitude towards others that are different exists as an intangible thing. Rather they are both imbued in what schooling experience is about, in other words what is contained in this space: the relationship of their bodies to spaces like classrooms and how they forged practices of tolerance and equal recognition of others:

One lives with different people, and one is in the same class with them, and one sits down next to them. It is a very different concept of equality learnt by boys and girls from other schools, who live in the same neighbourhood, who share the same hobbies and even look similar and who go to the slum once a month to do something about equality [...]. I think they go there knowing beforehand that it is another world quite far away from their own reality [...]. They could be very polite, but they neither mix with others nor develop deep friendships; yet here one could have a classmate who is tall and blond, or one who is short and with dark skin, or one with a surname like Pérez and another one with a 'gringo' ${ }^{8}$ surname. Yet all of us were equal (Interview with Bea, 2011).

Diversity, as described by Bea, exemplifies what is perceived as the spatial identity of public education at the group of emblematic schools. Yet within a discourse of quality education clearly defined by a narrative of meritocracy, there is little room to consider that what is lived at the emblematic schools is about spaces of equal opportunities for quality education in contexts of social mixing. Social mixing is what allows the repositioning of equality as a lived rather than a pre-given condition. To live equality, to be sitting down next to others different to us, is what makes the conditions - when "[...] the lived body experience is concerned” (Lefebvre, 1991, p. 40) - for producing spaces. It could be argued that any lived experience contained in this space is what finally translates both tolerance and learning with others into a political decision and paves the way for youth activism. This is not only because it is based on a rational decision but because it is also rather grounded in an everyday practice embedded in the conflict with which the constitution of subjectivities and spaces is imbued. In the next section, this article set out how geographies of exclusion and ties of solidarity shape different forms of student activism on the periphery.

\section{Youth Activism on the Periphery: geographies of exclusion and ties of solidarity}

Youth political activism at high schools in peripheral communes intersects with geographies of exclusion and ties of solidarity. Similarly, as at the emblematic schools, an understanding of practices and experiences of activism at schools in peripheral areas is framed within the formation of a historical identity of public education, interplaying with public school trajectories over 50 years. However, these are high schools that are not selective. Schools in peripheral areas have historically been affected by unequal inner urban development patterns of segregation and poverty, that have an influence on the formation of residential areas within these communes and have resulted in a more homogeneous

852 Educação \& Realidade, Porto Alegre, v. 43, n. 3, p. 837-862, July/Sept. 2018. 
socioeconomic composition. Yet patterns of student commuting are also to be found in these schools where students from the first four lowest income decile groups (see Image 4) commute to schools in communes like Recoleta, La Florida, La Cisterna and San Miguel (see Image 3). As a result, municipal high schools with the highest level of student enrolment in peripheral areas demonstrate a less homogeneous socioeconomic composition.

The extent to which some of these municipal high schools still maintain a high rate of student enrolment, comprising students from the lowest and low middle-income neighbourhoods, entails recognising “[...] the relationship of education to spatialised inequalities, identity and meaning" (Lipman, 2007, p. 157) in those peripheral communes. This process also emphasises the meaning of periphery "[...] as not simply a spatial solidification" (Smith, 1993, p. 101) that divides core and periphery, but rather different peripheries are to be found within the core-periphery spatial distinction.

How do these particular spatialised differentiations operate at schools in peripheral areas? They are depicted as discourses operating through class differentiation between people who are like or unlike us:

I had more cultural capital than my classmates did; at the age of thirteen, I had already read the Communist Manifesto and shared some books with friends at the school. At that time, I met my best friend; we were very close friends. He came from a family with a history of political persecution by the dictatorship. He had political capital in terms of social relations, experience, and networks. So it was a different sort of capital from mine. As we become friends we ended up building our own networks (Interview with Mauro, 2011).

Here, distinction relies on a mode of differentiation (Savage, 2000) that operates as a social filter (Reay, 1997) to locate political and social capital among students who recognised themselves as equal to others. Similarly, a material and symbolic distinction operates as a form of exclusion of those who are different from us. Sibley (1995) notes that geographies of exclusion operate as "[...] the production of bordered spaces in which only some are included” (Thomson, 2007, p. 117):

When I left the private school in Santiago city centre to continue at a municipal high school in the commune of San Miguel it was like breaking a bubble as I entered into an education space for poor students [...]. I was seen as the posh and privileged student. Although I come from La Cisterna I needed to break down some barriers and to learn new codes I did not know before (Interview with Mauro, 2011).

What does the possibility for inclusion of a student who comes from a different background rely on? Education plays a fuller role in this process whereby a limited context in which education takes places becomes at the same time an opportunity for transforming these kinds of barriers:

Well, I began to be included slowly; for me it was a long process to feel more adapted within this new space. Yet as I lived in the same commune 
Youth Activism in Chile

we began to share some spaces. This also happened at the school. I had some books that the school did not have, so I lent some of them to my classmates or they came to my house to do some homework together (Interview with Mauro, 2011).

Lipman (2008) notes that most of the evidence on peer influence shows the positive impact of middle-class students on educational experience within low-income contexts. Nevertheless, such evidence of the benefits of the proximity of middle-class students in contexts of poverty and exclusion seems to be framed within "[...] cultural deficit theories that situate educational outcomes in the characteristics of students" (Lipman, 2008, p. 125-126). A central question is posed as to how education could, in contexts of marginality, provide space for students to become political. This entails recognising that educational experience is a multifaceted phenomenon (Lipman, 2008) interwoven in the production of education space that might serve as "[...] control, and hence of domination of power" (Lefebvre, 1991, p. 26), but it also "[...] escapes in part from those who would make use of it" (Lefebvre, 1991, p. 26). For example, whilst student commuting either to the nearest school or to the nearest commune is determined by poverty, locality and distance it also opens up the possibility, notwithstanding how education space could be constrained, for building very close friendships:

They were friends, like life-long friends living in the same neighbourhood. I had never had friends like them; my friends lived in other communes and they commuted to Santiago just to study there. Here instead, the other guys, as they lived in nearby communes they were life-long friends, they played together, they studied and did homework together and they even drank a beer together [...]. I did not have this experience, so I saw them as much more fraternal and a more closed group too (Interview with Mauro, 2011).

Does distance shape a differentiated quality of friendship, solidarity, and affection at both schools in peripheral and central areas of Greater Santiago? Certainly, life-long friendship at schools in the peripheral areas seems to display a pattern of closeness grounded in daily schooling experience and practices. Yet distance limits neither the quality of friendship nor solidarity nor affection at schools with students commuting long distances. Rather, at these schools, friendship arises as a space of resistance and a counter-public space (Thomson, 2007) through which students at the emblematic schools re-imagine themselves by learning how to live together.

While historical experiences of student political activism at the emblematic schools influence the formation of a centralised urbanbased political movement, similar stories are also to be found at schools in peripheral communes. This tradition of student political activism is somehow forged in and through geographies of exclusion that can work powerfully to disrupt the production of bordered spaces, and in turn underline a spatialised politics of solidarity:

We were as fraternal to each other as we are to those excluded from the system. This was the only way to survive exclusion. There were differ- 
ences among us but, above all, we were united. I think the sociological axiom is to keep closed against threats from outside, right? Because of exclusion the only way to deal with this is by living together. A leftist culture has always existed at the school and I think that is because we believe in being united. It was the only way to fight for very local demands like, for example, eliminating mice at the school. These demands also led to more students being involved in politics (Interview with Mauro, 2011).

Since the meaning of exclusion is clearly connected to material place, for example, the lack of infrastructure at the school, being excluded might be framed in temporal terms. Yet this material place also represents a symbolic space since students reaffirm their sense of identity and their political activism. To some extent, these very local demands, rooted in what constrained daily schooling experience, became "[...] an extension of their new collective persona and signified materially/spatially the change in their social position in the school" (Thomson, 2007, p. 125).

A focus on what forms of student activism are displayed in contexts of exclusion might provide a more nuanced understanding of the assemblages of different forms of becoming political. Recognition of the production of ties of solidarity through geographies of exclusion unsettles the presumed modes of belonging (Turner, 2016) to students from disadvantaged socio-economic contexts. It entails acknowledging that forms of youth activism at schools in peripheral areas are deeply ingrained in spaces of resistance and contestation beyond a binary distinction of inclusion and exclusion. Marginality and exclusion encompasses a spatial dimension as the meaning of periphery is not static, but always in a state of flux. In doing so, it relocates forms of youth political activism in contexts of marginality as intersecting moments of conditions of possibility (Allen, 2002). These represent emerging spaces for political contestation to show that "[...] neoliberal economic and social processes" (Lipman, 2007, p. 70) in education becomes an arena of struggle to be resisted and contested in everyday practices of solidarity. This in turn relates to relational forms for the constitution of what is to be the political that equally leads to different forms of youth activism within the margins.

\section{Conclusion}

This paper examined the process through which youth activism develops through spatialities of inclusion and geographies of exclusion in which education is embedded and through exploring how students re-imagine themselves through these different spatialities of schooling experience. These geographical imaginaries (Hanson Thiem, 2009) have been examined beyond just a binary relationship of inclusion/exclusion, but rather as interconnected elements that are part of the formation of the political as spaces of living together and practices of solidarities as emergent moments that provide conditions for the political being (Turner, 2016) to come into existence. 
Youth Activism in Chile

Debates on the role that education plays out in the formation of civic attitudes and citizenship seem to move in two different directions. On the one hand it has been argued that a focus on inclusion frames different forms of becoming political within a "[...] territorialised regime of rights" (Turner, 2016, p. 142) in which rights are important for the political possibility of contestation but there is always a risk between claiming rights and the inclusion of this meaning of citizenship through " $[. .$. integrationist strategies, which provide rights on the conditions of behaviour, meritocracy, acting like a good citizen" (Brown, 1995, p. 121; Turner, 2014). And on the other hand, it is recognised that this political role of education is spatial since it is constituted through territorial affinities and diversity through which we ourselves are constituted in relation to others (Hanson Thiem, 2009).

Territoriality articulates different assemblages and practices of citizenship at schools. Overall, evidence shows that there is a relationship between civic knowledge performance and students' socio-economic backgrounds. Schools play a role in mitigating this relationship; however, most of the evidence does not connect analysis of this role of schools to the spatial. This spatial dimension involves acknowledging that schools produce practices and forms of civic and political engagement sedimented over time. Schools therefore carried collective memories.

The space-time of schools' trajectories in turn shapes a meaning of territory in which schools represent a key location of this territorial character. So forms of being political and different geographies of youth activism, such as locally specific-based practices displayed by schools from low income urban areas, are spatial. Through the lens of the spatial, analysis of the forms of political and youth activism implies recognition that these practices and experiences of the political are reshaped and re-contextualised at the intersection of both spatialities of urban educational inequalities and "[...] cultural, political and ideological [layers] which also have their local specificities” (Massey, 1984, p. 120). Then there are spatial assemblages of history and marginality through which democratic attitudes, struggles for belonging and alternative forms of activism are produced in particular places and times. The focus is then on a national curriculum for citizenship that recognises those marginal forms of youth activism as also "[...] delineat[ing] the contingency of citizenship itself" (Turner, 2016, p. 143).

Practices of solidarity and spaces of living together constitute forms of becoming political that intertwine with the spatial since they are embedded in co-existence with a multiplicity of trajectories (Massey, 1999). They become territorial as these practices and spaces of “[...] meeting up (or not) of [these] multiple trajectories" (Massey, 1999, p. 283) are relationally produced. It is through this context that the demand for the right to education has been re-shaped and re-contextualised spatially within the Chilean student movement. This equally leads to the question concerning the extent to which citizenship education could further move away from the language of marketisation and pri-

856 Educação \& Realidade, Porto Alegre, v. 43, n. 3, p. 837-862, July/Sept. 2018. 
vatisation, through which schools and education are often involved in “[...] regain[ing a] competitive edge" (Apple, 2013, p. 6) towards building political possibilities in which education and schooling experience are about "[...] contest[ing]... disput[ing] and interrupt[ing] dominant modes of belonging" (Turner, 2016, p. 144).

Looking at these spaces of political possibilities through education and schooling experience entails recognising citizenship education as an open space, engaging with different places, scales and territorialities that have been in a continuous process of re-conceptualising and re-shaping the meaning of what political being and activism have come to mean. The focus of Chilean civic education policies has been on prioritising "[...] democracy, citizens' rights and civic participation" (Treviño et al., 2017, p. 606). So a further critical challenge for a policy on a citizenship education curriculum is how it could prioritise fostering citizenship and deepening democracy through learning how public schools are engaging, despite the advance of urban neoliberal policies, with difference, diversity and inclusion.

Received on July 6, 2017 Approved on December 14, 2017

\section{Notes}

1 This article is based on an unpublished doctoral thesis on Space and Politics in the Penguins' movement: geographies of the political construction of the Chilean student movement, UCL Institute of Education, University College London. The author acknowledges the financial support of the Society for Latin American Studies (SLAS) in undertaking the fieldwork in Chile between July and November 2011.

2 The Metropolitan Region is classified as Greater Santiago and Suburban Santiago. Greater Santiago comprises 34 communes: Cerrillos, Cerro Navia, Conchalí, El Bosque, Estación Central, Huechuraba, Independencia, La Cisterna, La Florida, La Granja, La Pintana, La Reina, Las Condes, Lo Barnechea, Lo Espejo, Lo Prado, Macul, Maipú, Ñuñoa, Pedro Aguirre Cerda, Peñalolén, Providencia, Puente Alto, Quilicura, Quinta Normal, Recoleta, Renca. San Bernardo, San Joaquín, San Miguel, San Ramón, Santiago, Vitacura. Suburban Santiago comprises 18 communes: Alhué, Buin, Calera de Tango, Colina, Curacaví, El Monte, Isla Maipo, Lampa, María Pinto, Melipilla, Padre Hurtado, Paine, Peñaflor, Pirque, San José de Maipo, San Pedro, Talagante, Tiltil (Donoso-Díaz; Arias-Rojas, 2013).

3 Four governments of the Concertación assumed office between March 1990 and March 2010. The Concertación comprised the Partido Demócrata Cristiano (PDC [Christian Democratic Party]); Partido Socialista (PS [Socialist Party]); Partido por la Democracia (PPD [Party for Democracy]) and Partido Radical Socialdemócrata (PRSD [Radical Social Democratic Party]). The four governments were led by Patricio Alwyin (1990-1994) and Eduardo Frei Ruiz-Tagle (1994-2000) from PDC, Ricardo Lagos (2000-2006) from PPD and Michelle Bachelet (2006-2010) from PS.

4 The Nacional is a short name that students used when referring to the Instituto Nacional Jose Miguel Carrera in the commune of Santiago in Greater Santiago. 
5 The Aplicación is a colloquialism that students used when referring to the Liceo de Aplicación Rector Jorge E. Schneider in the commune of Santiago in Greater Santiago.

6 See Footnote 1.

7 Villa Francia is a shantytown (población) in the commune of Estación Central from Greater Santiago. It was one of the "poblaciones" that took a combative position against the military dictatorship.

8 Gringo is a colloquialism that refers to a foreign person.

\section{References}

ALLEN, Amy. Power, Subjectivity, and Agency: between Arendt and Foucault. International Journal of Philosophical Studies, Essex, v. 10, n. 2, p. 131-149, 2002.

ALLEN, John; MASSEY, Doreen; COCHRANE, Allan. Rethinking the Region. London: Routledge, 2000.

ALVARADO, Sara; VOMMARO, Pablo (Ed.). Jóvenes, Políticas y Culturas: experiencias, acercamientos y diversidades. Rosario: CLACSO Homosapiens, 2012.

APPLE, Michael. Can Education Change Society? New York: Routledge, 2013.

BAGGULEY, Paul. Middle Class Radicalism Revisited. In: BUTLER, Tim; SAVAGE, Mike (Ed.). Social Change and the Middle Classes. London: Macmillan, 1995. P. 293-312.

BELLEI, Cristián; CABALIN, Cristian. Chilean Student Movements: sustained struggle to transform a market-oriented educational system. Current Issues in Comparative Education, New York, v. 15, n. 2, p. 108-123, 2013.

BOURDIEU, Pierre. Distinction. Cambridge: Harvard University Press, 1984. BROWN, Wendy. States of Injury: power and freedom in late modernity. Princeton: Princeton University Press, 1995.

CAMPBELL, David; LEVINSON, Meira; HESS, Frederick (Ed.). Making Civics Count: citizenship education for a new generation. Cambridge: Harvard Education Press, 2012.

CASTILLO, Juan Carlos et al. Mitigating the Political Participation Gap from the School: the roles of civic knowledge and classroom climate. Journal of Youth Studies, London, v. 18, p. 16-35, 2014a.

CASTILLO, Juan Carlos et al. Social Inequality and Changes in Students' Expected Political Participation in Chile. Education, Citizenship and Social Justice, Belfast, v. 9, p. 140-156, 2014b.

CHARMAZ, Kathy. Constructing Grounded Theory. 2. ed. London: Sage, 2014.

COX, Cristián. Las Políticas Educacionales de Chile en las Últimas dos Décadas del Siglo XX. In: COX, Cristián (Ed.). Políticas Educacionales en el Cambio de Siglo: la reforma del sistema escolar. Santiago de Chile: Editorial Universitaria, 2003. P. 19-113.

COX, Cristián; JARAMILLO, Rosario; REIMERS, Fernando. Education for Democratic Citizenship in the Americas: an agenda for action. Washington: InterAmerican Development Bank, 2005.

DELLI CARPINI, Michael; KEETER, Scott. What Americans Know about Politics and why it Matters. New Heaven: Yale University Press, 1996.

858 Educação \& Realidade, Porto Alegre, v. 43, n. 3, p. 837-862, July/Sept. 2018. 
DONOSO, Sofía. Dynamics of Change in Chile: explaining the emergence of the 2006 Pinguino Movement. Journal of Latin American Studies, London, v. 45, n. 1, p. 1-29, 2013.

DONOSO-DÍAZ, Sebastián; ARIAS-ROJAS, Óscar. Desplazamiento Cotidiano de Estudiantes entre Comunas de Chile: evidencia y recomendaciones de politica para la nueva institucionalidad de la educacion pública. EURE, Santiago de Chile, v. 39, n. 116, p. 39-73, 2013. Available at: <http://www.scielo.cl/pdf/eure/ v39n116/art02.pdf $>$. Accessed on: 30 Jun. 2013.

ECONOMIC COMMISSION FOR LATIN AMERICAN AND THE CARIBBEAN (ECLAC). Juventud y Cohesión Social en Iberoamérica: un modelo para armar. Santiago de Chile: CEPAL, 2008.

FRASER, Nancy. An Extraordinary Protest just Disappeared. Green European Journal, Brussels, v. 11, p. 85-90, 2015.

GARNER, Catherine; RAUDENBUSH, Stephen. Neighbourhood Effects on Educational Attainment: a multilevel analysis. Sociology of Education, New York, v. 64, n. 4, p. 251-262, 1991.

GAVENTA, John. Triumph, Deficit or Contestation? Deepening the 'Deepening Democracy' Debate. IDS Working Paper, Brighton, n. 264, 2006.

GLASER, Barney. Theoretical Sensitivity: advances in the methodology of grounded theory. Mill Valley: The Sociology Press, 1978.

GUILlAUME, Xavier; HUYSMANS, Jeff (Ed.). Citizenship and Security: the constitution of political being. Abingdon: Routledge, 2013.

HANSON THIEM, Claudia. Thinking Through Education: the geographies of contemporary educational restructuring. Progress in Human Geography, Thousand Oaks, v. 33, n. 2, p. 154-173, 2009.

HARVEY, David. Spaces of Global Capitalism: towards a theory of uneven geographical development. London: Verso, 2006.

HERNANDEZ, Ivette. Which Education for which Democracy: the case of the Penguins' Revolution in Chile. In: MOTTA, Sara; COLE, Michael (Ed.). Education and Social Change in Latin America. New York: Palgrave Macmillan, 2013. P. 185-202.

HERNANDEZ, Ivette. Space and Politics in the Penguins' Movement: geographies of the political construction of the Chilean student movement. 2017. $348 \mathrm{f}$. Thesis (Doctorate in Education, Practice and Society) - Institute of Education, University College London, London, 2017.

HOOGHE, Marc; DASONVILLE, Ruth. Voters and Candidates in the Future: the intention of electoral participation among adolescents in 22 European countries. Young - Nordic Journal of Youth Research, Oslo, v. 21, p. 1-28, 2013.

ISAC, Maria Magdalena et al. The Contribution of Schooling to SecondarySchool Students' Citizenship Outcomes Across Countries. School Effectiveness and School Improvement, London, v. 25, p. 29-63, 2014.

JOHNSON, John. In-Depth Interviewing. In: GUBRIUM, Jaber; HOLSTEIN, James (Ed.). Handbook of Interview Research: context and method. Thousand Oaks: Sage, 2001. P. 103-119.

KIWAN, Dina. Human Rights and Citizenship Education: re-positioning the debate. Cambridge Journal of Education, New York, v. 42, n. 1, p. 1-7, 2012.

LARNER, Wendy. Neo-Liberalism: policy, ideology, governmentality. Studies in Political Economy, Ottawa, v. 63, p. 5025, 2000.

Educação \& Realidade, Porto Alegre, v. 43, n. 3, p. 837-862, July/Sept. 2018. 
LATIN AMERICAN PUBLIC OPINION PROJECT (LAPOP). Encuesta Opinión Pública de América Latina 2012. Tennessee: Vanderbilt University, 2012.

LAURIE, Nina; BONDI, Liz (Ed.). Working the Spaces of Neoliberalism: activism, professionalisation and incorporation. Malden: Blackwell, 2006.

LEFEBVRE, Henry. The Production of Space. London: Verso, 1991.

LIPMAN, Pauline. High Stakes Education: inequality, globalisation and urban school reform. New York: Routledge, 2004.

LIPMAN, Pauline. Education and the Spatialisation of Urban Inequality: a case study of Chicago's Renaissance. In: GULSON Kalervo; SYMES, Colin (Ed.). Spatial Theories of Education: policy and geography matters. New York: Routledge, 2007. P. 155-174.

LIPMAN, Pauline. Mixed-Income Schools and Housing: advancing the neoliberal urban agenda. Journal of Education Policy, London, v. 23, n. 2. p. 119-134, 2008.

LIPMAN, Pauline. The New Political Economy of Urban Education: neoliberalism, race and the right to the city. Oxon: Routledge, 2011.

MASSEY, Doreen. Spatial Divisions of Labour: social structures and the geography of production. Basingstoke: Macmillan, 1984.

MASSEY, Doreen. Space, Place and Gender. Minneapolis: University of Minnesota Press, 1994.

MASSEY, Doreen. Spaces of Politics. In: MASSEY, Doreen; ALLEN, John; SARRE, Philip (Ed.). Human Geography Today. Cambridge: Polity Press, 1999. P. 279294.

MASSEY, Doreen. Geographies of Responsibility. Geografiska Annaler - Series B, Human Geography, Helsingborg, v. 86, n. 1, p. 5-18, 2004.

MASSEY, Doreen. For Space. London: Sage, 2005.

MCCOWAN, Tristan. Reframing the Universal Right to Education. Comparative Education, London, v. 46, n. 4, p. 509-525, 2010.

MCCOWAN, Tristan. Human Rights within Education: assessing the justifications. Cambridge Journal of Education, New York, v. 42, n. 1, p. 67-81, 2012.

MEZZADRA, Sandro; NEILSON, Brett. Border as Method or the Multiplication of Labor. Durham: Duke University Press, 2013.

MITCHELL, Katharyne; MARSTON, Sallie; KATZ, Cindi (Ed.). Life's Work: geographies of social reproduction. Malden: Blackwell, 2004.

MULLER, Benjamin. (Dis)Qualified Bodies: securitization, citizenship and 'identity management'. Citizenship Studies, London, v. 8, n. 3, p. 279-294, 2004. NUÑEZ, Iván. Tradición, Reformas y Alternativas Educacionales en Chile: 1925-1973. Santiago de Chile: Centro de Estudios Económicos y Sociales, 1979.

NYERS, Peter (Ed.). Securitisation of Citizenship. Abingdon: Routledge, 2009.

PAKULSKI, Jan. Social Movements and Class: the decline of the Marxist paradigm. In: MAHEU, Louis (Ed.). Social Movements and Social Classes: the future of collective action. London: Sage, 1995. P. 55-86.

PAPADOPOULOS, Dimitris; NIAMH, Stephenson; VASSILIS, Tsianos. Escape Routes: control and subversion in the twenty first century. London: Pluto Books, 2008.

PORTA, Donatella della; DIANI, Mario. Social Movements: an introduction. 2. ed. Oxford: Blackwell Publishing, 2006.

860 Educação \& Realidade, Porto Alegre, v. 43, n. 3, p. 837-862, July/Sept. 2018. 
POSEY-MADDOX, Linn. From City to Suburb: examining the experiences and educational engagement of black parents in a suburban context. In: ANNUAL INTERNATIONAL CONFERENCE GEOGRAPHIES OF CO-PRODUCTION, 2014, London. Anals... London: Royal Geographical Society, 2014. P. 203.

REAY, Diane. Feminist Theory, Habitus, and Social Class: disrupting notions of classlessness. Women's Studies International Forum, Amsterdam, v. 20, n. 2, p. 225-233, 1997.

REIMERS, Fernando. Civic Education when Democracy is Flux: the impact of empirical research on policy and practice in Latin America. Citizenship and Teacher Education, College Park, v. 3, n. 2, p. 5-21, 2007.

RIGO, Enrica. Citizenship at Europe's Borders: some reflections of the post-colonial condition of Europe in the context of EU enlargement. Citizenship Studies, London, v. 9, n. 1, p. 3-22, 2005.

ROBERTS, Kenneth. Social Inequalities without Class Cleavages in Latin America's Neoliberal Era. Studies in Comparative International Development, Providence, v. 36, n. 4, p. 3-33, 2002.

RODRIGUEZ, Jorge. ¿Policentrismo o Ampliación de la Centralidad Historica en el Area Metropolitana del Gran Santiago? evidencia novedosa proveniente de la Encuesta Casen 2009. EURE, Santiago de Chile, v. 38, n. 114, p. 71-97, 2012. Available at: <http://www.scielo.cl/pdf/eure/v38n114/art03.pdf $\geq$. Last Accessed 30 Jun. 2013.

ROSENEIL, Sasha et al. Reproduction and Citizenship/Reproducing Citizens: editorial introduction. Citizenship Studies, London, v. 17, n. 8, p. 901-911, 2013. RUIZ ENCINA, Carlos; BOCCARDO, Giorgio. Los Chilenos Bajo el Neoliberalismo: clases y conflicto social. Santiago de Chile: El Desconcierto, 2015.

SAVAGE, Mike. Class Analysis and Social Transformation. Oxford: Oxford University Press, 2000.

SCHOLZMAN, Kay; VERBA, Sidney; BRADY, Henry; BURNS, Nancy. The Intergenerational persistence of economic inequality. In: SCHOLZMAN, Kay; VERBA, Sidney; BRADY, Henry (Ed.). The Unheavenly Chorus: unequal political voice and the broken promise of American democracy. Princeton: Princeton University Press, 2012. P. 177-198.

SCHULZ, Wolfram et al. ICCS 2009 International Report: civic knowledge, attitudes, and engagement among lower-secondary school students in 38 countries. Amsterdam: International Association for the Evaluation of Educational Achievement (IEA), 2010.

SCHULZ, Wolfram et al. ICCS 2009 Latin American Report: civic knowledge and attitudes among lower-secondary students in six Latin American countries. Amsterdam: IEA, 2011.

SEN, Amartya. Democracy as a Universal Value. Journal of Democracy, Washington, v. 10, n. 3, p. 13-16, 1999a.

SEN, Amartya. Development as Freedom. Oxford: Oxford University Press, $1999 b$

SIBLEY, David. Geographies of Exclusion: society and difference in the West. London: Routledge, 1995

SMITH, Neil. Homeless/Global: scaling places. In: BIRD, Jon; CURTIS, Barry; PUTNAM, Tim; ROBERTSON, George; TICKNER, Lisa (Ed.). Mapping the Futures: local cultures, global change. New York: Routledge, 1993. P. 87-119.

Educação \& Realidade, Porto Alegre, v. 43, n. 3, p. 837-862, July/Sept. 2018. 
SOJA, Edward. Preface. In: LEANDER, Kevin; SHEEHY, Margaret (Ed.). Spatialising Literacy Research and Practice. New York: Peter Lang, 2004. P. 9-16.

STARKEY, Hugh. Human Rights and Education. In: BANKS, James (Ed.). Encyclopedia of Diversity in Education. London: SAGE, 2012a. P. 1115-1118.

STARKEY, Hugh. Human Rights, Cosmopolitanism and Utopias: implications for citizenship education. Cambridge Journal of Education, Cambridge, v. 42, n. 1, p. 21-35, 2012b

TAYLOR, Marcus. From Pinochet to the 'Third Way': neoliberalism and social transformation in Chile. London: Pluto Press, 2006.

THOMSON, Pat. Working the In/Visible Geographies of Social Exclusion. In: GULSON, Kalervo; SYMES, Colin (Ed.). Spatial Theories of Education: policy and geography matters. New York: Routledge, 2007. P. 111-129.

THRIFT, Nigel. Knowing Capitalism. London: Sage, 2005.

TORNEY-PURTA, Judith. The School's Role in Developing Civic Engagement: a study of adolescent in twenty-eight countries. Applied Development Science, London, v. 6, p. 203-212, 2002.

TREVIÑO, Ernesto et al. Influence of Teachers and Schools on Students' Civic Outcomes in Latin America. The Journal of Educational Research, Oxfordshire, v. 100, n. 6, p. 604-618, 2017.

TURNER, Joe. Testing the Liberal Subject: (in)security, responsibility and selfimprovement in the UK citizenship test. Citizenship Studies, London, v. 18, n. 3-4, p. 332-348, 2014

TURNER, Joe. (En)Gendering the Political: citizenship from marginal spaces. Citizenship Studies, London, v. 20, n. 2, p. 141-155, 2016.

UNITED NATIONS DEVELOPMENT PROGRAMME. Informe sobre Desarrollo Humano para Mercosur 2009-2010 Innovar para Incluir: jóvenes y desarrollo humano. New York: UNDP, 2009.

VAN DER REE, Gerard. Contesting Modernities: projects of modernisation in Chile, 1964-2007. Amsterdam: Dutch University Press, 2007.

Ivette Hernandez Santibañez obtained her PhD in Sociology of Education from the UCL Institute of Education, University College London. Her research interests are located at the intersection of neoliberal economic policies in urban education and social movements, with a focus on progressive public policies on free education, grassroots student movements and radical democratic politics.

E-mail: ivehersant@gmail.com

This is an open-access article distributed under the terms of the Creative Commons Attribution License 4.0 International. Available at: <http://creativecommons.org/licenses/by/4.0>. 